\title{
Ribozyme Genes Protecting Transgenic Melon Plants Against Potyviruses
}

\author{
Eric Huttner ${ }^{1,5, *}$, William Tucker ${ }^{2}$, Agnès Vermeulen ${ }^{3}$, \\ Frédéric lgnart ${ }^{3}$, Brett Sawyer ${ }^{4}$, and Robert Birch ${ }^{4}$ \\ ${ }^{1}$ Biogemma, 1 Rue Edouard Colonne, 75001 Paris, \\ France \\ ${ }^{2}$ Groupe Limagrain Pacific, Canberra, Australia \\ ${ }^{3}$ Tézier, Valance, France \\ ${ }^{4}$ Department of Botany, University of Queensland, \\ Brisbane, Australia \\ ${ }^{5}$ Current address: Center for the Application of \\ Molecular Biology to International Agriculture, \\ GPO Box 3200, Canberra ACT 2601, Australia
}

\begin{abstract}
Potyviruses are the most important viral pathogens of crops worldwide. Under a contract with Gene Shears Pty Limited, we are using ribozyme genes to protect melon plants against two potyviruses: WMV2 and ZYMV. Different polyribozyme genes were designed, built and introduced into melons plants. Transgenic melon plants containing a resistance gene were obtained and their progeny was challenged by the appropriate virus. Most of the genes tested conferred some degree of resistance to the viruses in glasshouse trials. Melon plants from one family containing one gene directed against WMV2 were also field-trialed on small plots under natural infection pressure and were found immune to WMV2. Field trial is in progress for plants containing genes against ZYMV. Some of the ribozyme genes used in the plants were also assayed in a transient expression system in tobacco cells. This enabled us to study the sequence discrimination capacity of the ribozyme in the case of one ribozyme target site. We found that a mutated target GUG (non cleavable) was less susceptible to inhibition by the ribozyme gene than the corresponding wild type target GUA (cleavable).

Work is now in progress to incorporate multiple resistance genes in melon plants, in constructs designed in compliance with the evolving European regulations concerning transgenic plants. The use of ribozyme genes to protect plants against viruses provides an alternative to the technologies currently used for protecting crops against viruses, based on the concept of Pathogen Derived Resistance (see for example 14). In the light of concerns expressed by some plant virologists (13) about the use of viral genes in transgenic plants, it may be that ribozyme genes will find many uses in this area of agricultural biotechnology.
\end{abstract}

*For correspondence. Email eric.huttner@cambia.org;

Tel. +61(0)2 6246 4514; Fax. +61(0)2 62464501.
Introduction

The potyvirus group is the largest and economically the most important of the 34 plant virus groups and families recognised. About one third of all viruses known to infect plant species around the world are potyviruses. Potyviruses are transmitted in nature by aphids or in some cases by fungi, mites or whiteflies. Experimentally, potyviruses can be mechanically inoculated by rubbing a suspension of viral particles on an abraded leaf; this makes these viruses a convenient experimental model. Most potyviruses have a limited host range. The symptoms induced are quite diverse, including vein clearing, leaf mosaic, leaf distortion or necrosis, resulting in reduced plant vigour and growth. Fruits may also be mottled or deformed, in some cases severely reducing the yield and the commercial value of the infected crop.

Potyviruses have long and flexuous rod-shaped particles made of about 2000 copies of a coat protein subunit. The virus particle contains a single strand positivesense polyadenylated genomic RNA, about 9-10 kb long, covalently linked in 5 ' to a protein called VPg. The genomic RNA encodes a large (340-370 $\mathrm{kDa})$ polyprotein which is ultimately cleaved into eight polypeptides through the action of three proteinases, two of them virus-encoded. Most relevant to this work are the three carboxy-terminal proteins: Nuclear inclusion a (Nia) believed to be a proteinase, Nuclear inclusion b ( $\mathrm{Nib}$ ) which is the viral replicase and the Coat Protein (CP). The virus replicates through a minus strand intermediate RNA copy of the genomic RNA.

Melon is the seventh largest vegetable crop in the world in value. In the Mediterranean region, the major viral pathogens of melon crops are the two potyviruses Watermelon Mosaic Virus 2 (WMV2) and Zucchini Yellow Mosaic Virus (ZYMV) and the cucumovirus Cucumber Mosaic Virus (CMV). Although some resistance genes exist for CMV and ZYMV, their introgression into commercial cultivars is long and cumbersome. No resistance gene for WMV2 has been identified so far. There is therefore a large interest in developing transgenic technologies to protect melon plants against those viral pathogens. Pathogen Derived Resistance (PDR) technology has been extensively explored to protect plants against these viruses. For example transgenic squash plants containing coat protein genes from CMV, WMV2 and ZYMV were obtained by the company Asgrow (now Seminis) (1). Similarly Harris Moran Seed Company has obtained melon plants protected against all three viruses using coat protein genes (2).

In this paper we will describe progress made by Gene Shears Pty Limited in generating transgenic melon plants protected against infection by WMV2 and ZYMV using multimeric hammerhead ribozyme genes. The work was done under a collaboration between Gene Shears and Tézier, the leading European melon breeding company, 
Table 1. Example of Possible Ribozyme Target Sequences

\begin{tabular}{|c|c|c|c|c|}
\hline $\begin{array}{l}\text { For the plus strand: } \\
\text { Aminoacid sequence: } \\
\text { Nucleotide sequence: }\end{array}$ & $\begin{array}{l}\text { MetSer } \\
\text { AUGUCN }\end{array}$ & $\begin{array}{l}\text { MetTyr } \\
\text { AUGUAU/C }\end{array}$ & $\begin{array}{l}\text { MetPhe } \\
\text { AUGUUU/C }\end{array}$ & $\begin{array}{l}\text { Phe } \\
\text { UUU/C }\end{array}$ \\
\hline \multicolumn{2}{|c|}{$\begin{array}{l}\text { For the minus strand: } \\
\text { Aminoacid sequence }(+) \text { : MetLys } \\
\text { Nucleotide sequence (+): 5'AUGAAA/G } \\
\text { Nucleotide sequence (-): 3'UACUUU/C }\end{array}$} & $\begin{array}{l}\text { MetThr } \\
\text { AUGACN } \\
\text { UACUGN }\end{array}$ & $\begin{array}{l}\text { GluLys } \\
\text { GAA/GAAA/G } \\
\text { CUU/CUUU/C }\end{array}$ & $\begin{array}{l}\text { Tyr } \\
\text { UAU/C } \\
\text { AUA/G }\end{array}$ \\
\hline
\end{tabular}

part of the Vilmorin Clause \& Co group. Melon plants protected by ribozyme genes against CMV infection had been obtained previously (3) in a collaboration between Gene Shears and Tézier. The strategy we followed was as follows:

Part of the sequence of the target virus genome was determined. Several polyribozymes were then designed and gene constructs expressing the ribozymes were built and introduced in melon plants. The transgenic melon plants were allowed to self and their unselected progeny was challenged with the relevant virus. Segregation of the resistance phenotype demonstrated the efficacy of the gene. One transgenic family was then used in a small scale field trial with natural inoculation of WMV2 (by aphids). In parallel, transient expression assay of ribozyme activity was done with some constructs in tobacco cells to refine our understanding of ribozyme functionality.

\section{Ribozyme Gene Design and Construction}

\section{Site Selection}

We determined about $3 \mathrm{~kb}$ of $3^{\prime}$ end nucleotide sequence of the genome of two field isolates of WMV2 and ZYMV. The sequence contains part of the region coding for Nia, the complete region coding for $\mathrm{Nib}$ and $\mathrm{CP}$, and ends at the polyA tail present at the $3^{\prime}$ end of the viral genome. Analysis of these sequences and comparison with published sequences allowed us to identify conserved regions for each virus which we chose as target sites for ribozymes.

Both the plus (+, coding, genomic) RNA strand of the virus and the minus (-, non-coding, replication intermediate)
RNA strand of the virus were targeted by ribozymes. The following criteria were used when choosing cleavage sites on the target RNA:

a. Triplets known to be well cleaved in vitro were preferred (5): GUC, GUA, GUU, UUC, UUU.

b. Triplets where the coding sequence had limited degeneracy were preferred.

The limited degeneracy increases the chance that the target sequence will not evolve easily so that the virus overcomes the resistance. Some examples are shown on Table 1 for illustration, with the cleaved triplet in Bold. Many more combinations are possible.

Triplets located in a region of sequence conservation were preferred. This would increase the chance that the ribozyme could target multiple strains of the virus or even multiple species of related viruses. It would also decrease the chance that a virus resistant to cleavage arises.

\section{Construction of Polyribozyme Genes Against WMV2}

\section{Site Selection}

Four sites were selected on the plus strand and four sites were selected on the minus strand. The sites are described on Table 2. The number used to describe a given ribozyme refers to the base underlined, on the + strand in Table 2 , according to the arbitrary numbering of the sequence we determined.

Of these sites, site 2259 was conserved in ZYMV. Site 1747 was highly conserved among most potyviruses: a comparison of a 23 base segment surrounding the site

Table 2. Ribozyme Target Sites Chosen for WMV2

Sites selected on the minus strand:

\begin{tabular}{lccc} 
Number & Target sequence & + strand sequence & Aminoacid sequence \\
\hline 696 & $5^{\prime}$ UUC - A 3' & $5^{\prime}$ UGAA 3' & Met Lys \\
996 & $5^{\prime}$ GUC - A 3' & $5^{\prime}$ UGAC 3' & Met Thr \\
1747 & $5^{\prime}$ GUA - U 3' & $5^{\prime}$ AUAC 3' & Tyr \\
2067 & $5^{\prime}$ UUU - G 3' & $5^{\prime}$ CAAA 3 & Thr Lys \\
These four sites are located in the region coding for proteins Nia and Nib.
\end{tabular}

Sites selected on the plus strand:

\begin{tabular}{lcc} 
Number & Target sequence & Aminoacid sequence \\
\hline 2259 & $5^{\prime}$ UUU - A 3' & Phe \\
2403 & $5^{\prime}$ UUUC - U 3' & Phe \\
2520 & $5^{\prime}$ UUUU - U 3' & Phe \\
2720 & $5^{\prime}$ GU A - A 3' & Gln Och \\
These four sites are located in the region coding for the coat protein.
\end{tabular}

Cleavage site is in Bold and the cleaved bond is indicated by a -. 
Table 3. Primers used to Build the Long Arm Polyribozyme Againts WMV2 Minus Strand

\begin{tabular}{lr}
\hline Rbz696-3': & 5'gtgaggacgaaAAAGCTGCTGTCGGTGCTC3' \\
Rbz696-5': & 3'CTAAATACCTAGGGACTTGTAgactactcagg5' \\
Result for 696: & 5'...GAACAUcugaugaguccgugaggacgaaAAAGC...3' \\
Rbz996-3': & 5'gtgaggacgaaACTAAGTTTTATGGGGGTTGG3' \\
Rbz996-5': & 3'CAGGTACCTGTCAACCGTAgactactcagg5' \\
Rbz1747-3': & 5'gtgaggacgaaACATAGCTGAGACAGCATTG \\
Rbz1747-5': & 3'CGTAGGCCTTTTCGAGGTgactactcagg5' \\
Rbz2067-3': & 5'gtgaggacgaaAAGAAAATGAACCTTCCAACAG3' \\
Rbz2067-5': & 3'GGGTGCTGATGTTTTCTATTGgactactcagg5'
\end{tabular}

Bases in lower case are encoding the ribozyme catalytic sequence. Bases in upper case are complementary to the target region and used to prime the plasmid template. Bases paired with the first two bases of the cleaved triplet are in bold. For the first primer pair the sequence of the final product around site 696 is shown, to demonstrate that ligation of the IPCR product will produce a molecule with a functional catalytic sequence inserted in replacement of the third base of the target site.

shows the following conservation:

ZYMV: $23 / 23$

Potato Virus Y: 20 / 22

Sugar Cane Mosaic Virus: 19 / 23

Pea Seed-borne Mosaic Virus: 20 / 23

Plum Pox Virus: 20 / 23

Maize Dwarf Mosaic Virus: 20 / 23

Construction of a Long Arm Ribozyme Gene Against the Minus Strand

A subclone of the cDNA for the 3' region of WMV2, approximately $1.9 \mathrm{~kb}$ in length was used as a template. Inverse PCR (IPCR) reactions were used to insert a ribozyme catalytic sequence in replacement of the third base of each target triplet, essentially as described in reference 15 . The ribozyme catalytic sequence from the satellite of Tobacco Ringspot Virus (sTobRV) (4) was used. The primers used are listed in Table 3.

The plasmid template was amplified by IPCR using the first pair of primers. The full length PCR product was purified on a gel, and circularised by ligation. The circular product was transformed into bacteria, and the resulting plasmid was extracted from a bacterial colony and submitted to the second IPCR reaction using the second pair of primers. The procedure was repeated with the third and fourth pair, and the final product was analysed by sequencing the modified regions. Errors were repaired by new rounds of IPCR when necessary. The final product had the expected sequence except at site 996 where the catalytic sequence is mutated in the ribozyme loop (upper case):
Mutant ribozyme in 996: cugaugaguccCAGggacgaa instead of:

Wild type sTobRV: cugaugaguccGUGAggacgaa.

To build a functional polyribozyme gene in a plant transformation vector, the multimeric long arm ribozyme sequence was cloned in a plant expression cassette made of the enhanced $35 \mathrm{~S}$ promoter from Cauliflower Mosaic Virus and the nos terminator (from pBIOS512, a derivative of pBIOS3 (6)), and the gene was then inserted in the plant transformation vector pSCK (a derivative of pSCV1 (7)) yielding plasmid pBPL3817. It contains a T-DNA with a marker gene conferring resistance to kanamycin and the long arm ribozyme gene expressing an RNA with approximately 1900 bases complementary to the minus strand of the virus (the target RNA) and targeting four sites on the target RNA.

Construction of a Long Arm Ribozyme Gene Against the Plus Strand

A procedure similar to that described above was used to built a ribozyme gene against the + strand. The plasmid template used in the IPCR reactions extended over the $3^{\prime}$ end 830 bases of WMV2, including $18 \mathrm{~A}$ of the polyA tail.Inverse PCR reactions were used as described above with the primer pairs described in Table 4.

The sequence of the obtained plasmid showed correct ribozyme sequence for sites 2259 and 2403 while ribozyme sequences for sites 2520 and 2720 each have one base deleted:

Table 4. Primers used to Build the Long Arm Polyribozyme Against WMV2 Plus Strand

\begin{tabular}{cr} 
Rbz2259+3': & 5'gtgaggacgaaAAACCATTCATAATCACACCC3' \\
Rbz2259+5': & 3'CAATAGCTATGTGGTTTGGTAgactactcagg5' \\
Rbz2403+3': & 5'gtgaggacgaaAAATGGTGCATGATTTGTC3' \\
Rbz2403+5': & 3'CGAAGACGACGCAGACTgactactcagg5' \\
Rbz2520+3': & 5'gtgaggacgaAAGTCAAAAGCATAGCGTGC3' \\
Rbz2520+5': & 3'CACAAAACCTTCATTGGAGTATgactactcagg5' \\
Rbz2720+3': & 5'gtgaggacgaACTGCGGTGGACCCATACC3' \\
Rbz2720+5': & 3'CACTGGTCAAATGGATCAGAAgactactcagg5' \\
\hline
\end{tabular}

(same notations as above) 
Table 5. Primers used to Build a Short Arm Polyribozyme Against WMV2

\begin{tabular}{ll} 
For the minus strand & \\
WM2067S & gcagctgctggatccatgTCATTTTCTTttcgcgtcaccgctcatcagGTTATCTTTTG \\
WM1747S & TCAGCTATGTttcgcgtcaccgctcatcagTGGAGCTTTC \\
WM996S & CagatctATAAAACTTAGTttcgcgtcaccgctcatcagATGCCAACTG \\
WM696S & CAGCAGCTTTttcgcgtcaccgctcatcagATGTTCAGGGAcctgcatctgatcaagcttg \\
\hline $\begin{array}{ll}\text { For the plus strand } \\
\text { WM2259S }\end{array}$ \\
$\begin{array}{ll}\text { WM2403S } & \text { TcagctgctggatccATGAATGGTTTttcgcgtcaccgctcatcagATGGTTTGG } \\
\text { WM2520S } & \text { CTTCCATTTttcgcgtcaccgctcatcagTCAGACGCAGat } \\
\text { WM2720S } & \text { CACCGCAGTttcgcgtcaccgctcatcagTATGAGGTTAC }\end{array}$
\end{tabular}

Lower case letters show the ribozyme catalytic sequence, lower italic letters show linker regions, upper case letters show target sequences. All sequences are shown $5^{\prime}$ to $3^{\prime}$. The sequence synthesised (shown) is actually the strand complementary to the ribozyme RNA.

Mutant ribozyme in 2520: Mutant ribozyme in 2720: Wild type sTobRV:
cugaugaguccUGAggacgaa cugaugagucGUGAGgacgaa cugaugaguccGUGAggacgaa
These mutations are known not to abolish ribozyme activity. This was confirmed by in vitro assays. The ribozyme sequence was cloned in the expression cassette of pBIOS512 as described above and the gene was then transferred to the plant transformation vector $\mathrm{pSCK}$ as described above yielding plasmid pBPL38010. pBPL38010 contains a T-DNA with a marker gene conferring resistance to kanamycin and the ribozyme gene expressing an RNA with approximately 830 bases complementary to the plus strand of the virus (the target RNA) and targeting four sites on the target RNA.

Construction of a Short Arm Ribozyme Gene Against the Plus and Minus Strand

In order to build a short arm multimeric ribozyme targeting the sites described above for the long arm ribozymes, synthetic oligonucleotides encompassing the entire sequence of the desired ribozyme gene were purchased. The oligonucleotides were assembled and the desired full length product was obtained using Ligation based PCR
(LbPCR) as described previously (8). The short arm multimeric ribozyme genes against the minus strand and the plus strand were synthesised independently and assembled using restriction sites built at the end of the synthetic sequences. The ribozyme catalytic sequence used for these construct is a variant of the sTobRV ribozyme, with a 3 base-pair GCG helix II instead of the natural 4 base-pair GUCC helix II. The pairing regions between the ribozymes and the target (helix I and helix III) were 10 to 12 bases in length. The sequence of the oligonucleotides used is given in Table 5 .

The $3^{\prime}$ non coding region of one strain of WMV2 (3' UTR) was then cloned in $3^{\prime}$ of the multimeric ribozyme sequence. This was done as an attempt to increase the efficacy of the ribozyme by co-compartmentalisation with the target viral RNA. If the 3 ' end sequence of the virus genome is involved in the cellular localisation of the genomic RNA, it was hoped that by providing the ribozyme RNA with a 3' sequence similar to that of its target, the two molecules would be present in the same cellular compartment, as has been described in animal cells for HIV (9). The fragment used contains the 3 ' 300 bases, which contains the last 14 codons of the cDNA followed by the complete untranslated region. The functional gene was built

Table 6. Ribozyme Target Sites Selected on ZYMV

\begin{tabular}{|c|c|c|c|c|}
\hline \multicolumn{5}{|c|}{ Sites selected on the minus strand: } \\
\hline $\begin{array}{l}\text { Number } \\
1245 \\
1743 \\
1929 \\
2009 \\
2027 \\
2354 \\
2442 \\
2564 \\
\end{array}$ & $\begin{array}{c}\text { Target sequence } \\
\text { 5' GUU - G } 3^{\prime} \\
\text { 5' GUA - U 3' } \\
\text { 5' GUC - A 3 } \\
\text { 5' UUC - A 3' } \\
\text { 5' UUC - C } 3^{\prime} \\
\text { 5' UUU - U } 3^{\prime} \\
\text { 5' GUA - U 3 } \\
\text { 5' } \\
\text { 5' UUC - A } 3^{\prime} \\
\end{array}$ & $\begin{array}{c}\text { + strand sequer } \\
5^{\prime} \text {, } \text { AAC } 3^{\prime} \\
5^{\prime} \text { AUAC } 3^{\prime} \\
5^{\prime} \text { UGAC } 3^{\prime} \\
5^{\prime} \text { UGAA } 3^{\prime} \\
5^{\prime} \text { GGAA } 3^{\prime} \\
5^{\prime} \text { AAAAA } 3^{\prime} \\
5^{\prime} \text { AUAC } 3^{\prime} \\
5^{\prime} \text { UGAA } 3^{\prime} \\
\end{array}$ & $\begin{array}{l}\text { eAminoacid } \\
\text { Asn } \\
\text { Tyr } \\
\text { Asp } \\
\text { ValAsn } \\
\text { GlyLys } \\
\text { GluAsn } \\
\text { Tyr } \\
\text { MetLys } \\
\end{array}$ & $\begin{array}{l}\text { Region encoding } \\
\text { Nib } \\
\text { Nib } \\
\text { Nib } \\
\text { CP } \\
\text { CP } \\
\text { CP } \\
\text { CP } \\
\text { CP } \\
\end{array}$ \\
\hline \multicolumn{5}{|c|}{ Sites selected on the plus strand: } \\
\hline $\begin{array}{l}\text { Number } \\
110 \\
2161 \\
2255 \\
2455 \\
2466 \\
2590 \\
2603\end{array}$ & 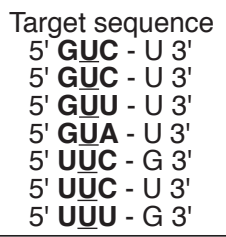 & $\begin{array}{l}\text { Aminoacid } \\
\text { Val } \\
\text { AlaSer } \\
\text { Val } \\
\text { ArgTyr } \\
\text { LeuArg } \\
\text { ValSer } \\
\text { Phe }\end{array}$ & \multicolumn{2}{|c|}{$\begin{array}{l}\text { Region encoding } \\
\text { Nia } \\
\text { CP } \\
\text { CP } \\
\text { CP } \\
\text { CP } \\
\text { CP } \\
\text { CP }\end{array}$} \\
\hline
\end{tabular}

Notation as in Table 2. 
as above yielding plasmid pBPL3754. pBPL3754 contains a T-DNA with a marker gene conferring resistance to kanamycin and the ribozyme gene expressing an RNA approximately 700 bases long. This RNA contains eight regions of homology to the plus or minus strand of the virus. Each region is between 20 and 22 bases long, and is split in the middle by the ribozyme catalytic sequence. In addition the ribozyme RNA has a 3 ' region containing approximately 300 bases identical to the viral 3 ' end.

\section{Construction of Polyribozymes Against ZYMV}

\section{Site Selection}

Site selection will be described using the same notations as above. The sites selected are described in Table 6.

Construction of a Long Arm Ribozyme Gene Against the Plus and the Minus Strand

A single gene, expressing one ribozyme RNA targeting several sites on both strands was made. The sites chosen were: $2009(-), 2027(-), 2354(-), 2455(+), 2466(+), 2590$ $(+)$ and $2603(+)$. To create the appropriate template, two fragments from the cDNA of the $3^{\prime}$ region of ZYMV were cloned in opposite orientation resulting in a plasmid containing the sequence between bases 2383 and 1961 linked to the sequence between bases 2388 and 2922. The ligation places side by side the region $3^{\prime}$ of 1961 and the region $3^{\prime}$ of 2383 . When a promoter is placed in the appropriate orientation, the transcription product of this sequence will be complementary to the minus strand of ZYMV between base 1961 and 2383, and complementary to the plus strand of ZYMV between base 2388 and 2922.

Ribozyme catalytic sequences were inserted at the positions mentioned above using a sequence of IPCR reactions on the template plasmid, following the procedure described for WMV2. The ribozyme catalytic sequence used for this construct was the natural sTobRV hammerhead ribozyme. The functional gene was built as above yielding plasmid pBPL4771 which contains a T-DNA with a marker gene conferring resistance to kanamycin and the long arm ribozyme gene expressing an RNA with approximately 900 bases complementary to the plus and minus strand of ZYMV RNA and targeting seven sites on the target RNAs.

\section{Construction of a Short Arm Ribozyme Gene Against the} Plus and Minus Strand

Several combinations of short arm ribozymes were built using synthetic oligonucleotides and the procedure described above. The first combination contained 10 ribozyme activities, 5 against each strand: 1245 - 1743 1929 - 2442 - 2564 against the minus strand; 110 - 2161 2255 - 2455 - 2590 against the plus strand. The ribozyme catalytic sequence used for these constructs was the variant of the sTobRV ribozyme described above, with a 3 base-pair GCG helix II. The pairing regions between the ribozymes and the target (helix I and helix III) were 8 to 11 bases.

The sequences were assembled together with the 3'UTR of WMV2 as described above. The resulting plasmid contained the sequence for the ribozymes against the plus strand, followed by the ribozymes against the minus strand followed by the 3'UTR. The functional gene was built as above yielding plasmid pBPL3906. pBPL3906 contains a T-DNA with a marker gene conferring resistance to kanamycin and the ribozyme gene expressing an RNA approximately 750 bases long. This RNA contains 10 regions of homology to the plus or minus strand of ZYMV. Each region is between 16 and 20 bases long, and is split in the middle by the ribozyme catalytic sequence. In addition the ribozyme RNA has a 3 ' region containing approximately 300 bases identical to the non translated $3^{\prime}$ end of WMV2 Val3.

A second combination was made using the following ribozymes: $2354(-)$ - $2455(+)$ - 2466 (+) - 2590 (+) - 2603 $(+)$. This was an attempt to benefit from the clustering of sites $2455-2466$ and 2590-2603. The ribozyme catalytic sequence used for these construct was the natural STobRV hammerhead ribozyme except for 2354 and 2603 where the same variant of the sTobRV ribozyme as described above, with a 3 base-pair GCG helix was used. The pairing regions between the ribozymes and the target (helix I and helix III) were 8 to 12 bases. Adjacent ribozymes 24552466 and 2590-2603 had one helix in common.

The functional gene was built as above yielding plasmid pBPL4186. pBPL4186 contains a T-DNA with a marker gene conferring resistance to kanamycin and the ribozyme gene expressing an RNA approximately 250 bases long. This RNA contains 3 regions of homology to the plus and minus strand of ZYMV. One region of 21 bases is split in the middle by one ribozyme catalytic sequence. The other 2 regions of 31 and 32 bases are each split in three parts by two ribozyme catalytic sequences.

A third combination was made using a double ribozyme against sites 2009 - 2027 (both minus strand). The ribozyme catalytic sequence used for this construct was the same variant of the sTobRV ribozyme as described above, with a 3 base-pair GCG helix II. The pairing regions between the ribozymes and the target (helix I and helix III) was made of 2 arms of 10 and 17 bases for each ribozyme. The 17 base arm was shared between the 2 ribozymes. In effect the total pairing region was 37 bases $(10+17+10)$, interrupted in 2 places by the 2 ribozyme sequences. The functional gene was built as above yielding plasmid pBPL4194. pBPL4194 contains a T-DNA with a marker gene conferring resistance to kanamycin and the ribozyme gene expressing an RNA approximately 100 bases long. This RNA contains 1 region of homology to the minus strand of ZYMV. The region is 37 bases long, and is split in three parts by the 2 ribozyme catalytic sequences.

All the polyribozymes described have some cleavage activity in vitro when assayed on uniformly labelled long target RNA (1.0 to $2.0 \mathrm{~kb}$ ). However we did not perform an exhaustive study and therefore cannot easily compare the various ribozyme activities present on a single construct. It was clear nevertheless that not all sites cleave equally well. At room temperature, only some of the sites could be cleaved. We were unsuccessful in predicting in vitro activity using computer-assisted modeling of RNA secondary structure. 
Table 7. WMV2 Challenge of Transgenic Plants in the Glasshouse

\begin{tabular}{lcccc}
\hline Plasmid & $\begin{array}{c}\text { Resistance } \\
\text { when Heterozygous }\end{array}$ & $\begin{array}{c}\text { Resistance } \\
\text { when Homozygous }\end{array}$ & $\begin{array}{c}\text { Resistance } \\
\text { Unclear }\end{array}$ & No Resistance \\
\hline pBPL3817 & 10 & 4 & 5 & 2 \\
pBPL3810 & 1 & 8 & 3 & 3 \\
pBPL3754 & 0 & 5 & 1 & 2 \\
\hline
\end{tabular}

Number of $\mathrm{T} 1$ families in each category of phenotype.

\section{Analysis of Transgenic Melon Plants Containing Ribozyme Genes}

Transgenic plants containing different ribozyme genes were obtained using methods described for example in US Patent 5,422,259. The plants were allowed to self and their progeny (T1 seeds) was harvested. The plants were then tested in the glasshouse for their response to infection by the viruses.

\section{Glasshouse Results with WMV2}

About $48 \mathrm{~T} 1$ seeds from each primary transformant were planted on soil and mechanically inoculated with the relevant virus. The level of infection was visually scored and the percentage of resistant plants was recorded. The percentage of resistant plants in each family provides an indication of the genetic determinism of the phenotype: for example, when $25 \%$ of the plants are resistant, we assume that the transgene in this family is conferring a resistance phenotype when present in the homozygous condition. The results are presented in Table 7.

As commonly observed in transgenic plants, a range of phenotype is obtained for each gene, presumably caused by differences in the position of the transgene in the genome (position effect). The comparison between constructs is made difficult by the small number of lines analysed. However it is clear that protecting against WMV2 is quite easy since resistant plants could easily be obtained with all the constructs.

The gene encoding a long arm polyribozyme against the minus strand (pBPL3817) seems the most efficient. The minus strand copy of the genomic RNA might be a better target than the plus strand. A similar phenomenon was described by Atkins et al. (10) and Yang et al. (11). Alternatively, this result could be caused by the presence on the polyribozyme against the minus strand of a more active catalytic unit. The presence of the viral 3' UTR in the short arm construct does not confer a clear advantage. However since no direct comparison was made, we cannot definitely rule out that the $3^{\prime}$ UTR has some effect. Line W38 containing the gene from pBPL3817 and showing good resistance was then chosen for further study.

\section{Field Trial with WMV2}

A homozygous transgenic plant from line W38 was identified at the next generation. Molecular analysis of its genomic DNA showed a single locus integration of the TDNA. The homozygous plant was then crossed to a non transgenic line and the progeny ( $\mathrm{F} 1$ hybrids) was planted in Spain in an area where WMV2 infection is high. The transgenic $\mathrm{F} 1$ hybrid plants were planted together with non transgenic parent plants and other control plants. Plants were grown under normal agronomical practice and scored three times during the season for virus symptoms. Non transgenic parent plants and control plants were heavily attacked by WMV2, showing that the infection pressure was high that year in this area. The identity of the virus was verified by ELISA. By contrast, at the end of the season, all the transgenic $\mathrm{F} 1$ hybrid plants had remained immune to WMV2.

\section{Glasshouse Results with ZYMV}

Because of the difference in the symptoms they cause in the field, two strains of ZYMV were used in the test. Strain 13-18 causes a necrotic reaction on some melon varieties, while strain E15 causes a mosaic. Results are presented in Table 8. The small number of plants obtained with the various constructs against ZYMV makes it very difficult to compare between constructs. However it seems that the

Table 8. ZYMV Challenge of Transgenic Plants in the Glasshouse

\begin{tabular}{lcccc}
\hline Plasmid & $\begin{array}{l}\text { Resistance } \\
\text { when Heterozygous }\end{array}$ & $\begin{array}{l}\text { Resistance } \\
\text { when Homozygous }\end{array}$ & $\begin{array}{l}\text { Resistance } \\
\text { Unclear }\end{array}$ & No Resistance \\
\hline With strain 13-18 & & & & \\
pBPL4771 & 1 & 1 & 0 & 0 \\
pBPL3906 & 0 & 4 & 1 & 3 \\
pBPL4186 & 0 & 1 & 2 & 3 \\
pBPL4194 & 0 & 2 & & \\
\hline With strain E15 & & & 1 & 1 \\
pBPL4771 & 2 & 2 & 0 & 9 \\
pBPL3906 & 0 & 0 & 0 & 3 \\
pBPL4186 & 0 & 0 & 0 & 6 \\
pBPL4194 & 0 & 0 & & \\
\hline
\end{tabular}

Same notation as Table 7. 
Table 9. Plasmids Used in the Transient Assay of Anti-Viral Polyribozymes

\begin{tabular}{|c|c|}
\hline Reporter Gene & 5' Fusion with Luciferase \\
\hline $\begin{array}{l}\text { pBPL0184 } \\
\text { pBPL0185 } \\
\text { pBPL0186 } \\
\text { pBPL0187 } \\
\text { pBPL0188 } \\
\text { pBPL0199 }\end{array}$ & $\begin{array}{l}\text { approx. } 200 \text { bases of WMV2 - centred around site } 696 . \\
\text { approx. } 200 \text { bases of WMV2 - centred around site } 996 . \\
\text { approx. } 200 \text { bases of WMV2 - centred around site } 1747 \text { (GUA). } \\
\text { approx. } 200 \text { bases of WMV2 - centred around site } 2067 . \\
540 \text { bases of WMV2 + containing sites } 2259,2403,2520,2720 . \\
\text { approx. } 200 \text { bases of WMV2 - centred around mutant site } 1747 \text { (GUG). }\end{array}$ \\
\hline \multicolumn{2}{|c|}{ Ribozyme Genes } \\
\hline pBPL0189 & $\begin{array}{l}\text { Octaribozyme from pBPL3754 (short arm, against WMV2 + and - strand). } \\
\text { potential targets: pBPL0184, 0185, 0186,0187, 0188, } 0199 .\end{array}$ \\
\hline pBPL0190 & $\begin{array}{l}\text { Pentaribozyme (short arm) against ZYMV - sites 1245, 1743, 1929, } 2442,2564 . \\
\text { potential targets: pBPL0186 and } 0199 \text { (because site } 1747 \text { in WMV2 - is conserved } \\
\text { in ZYMV - as site 1743). }\end{array}$ \\
\hline pBPL0195 & $\begin{array}{l}\text { Tetraribozyme from pBPL3817 (long arm against WMV2 - strand). } \\
\text { potential targets: pBPL0184, 0185, 0186, 0187, } 0199 .\end{array}$ \\
\hline pBPL0197 & $\begin{array}{l}\text { Tetraribozyme from pBPL } 38010 \text { (long arm, against WMV2 + strand). } \\
\text { potential target: pBPL0188. }\end{array}$ \\
\hline
\end{tabular}

long arm polyribozyme is more efficient at protecting plants against ZYMV. A difference was observed between the two strains used in the test: it was much easier to obtain transgenic lines resistant to strain 13-18. Strain E15 was the strain initially sequenced and this sequence was used for the design of the ribozymes. It is therefore unlikely that sequence polymorphism explains the inability of most of the ribozyme genes to protect against strain E15. The difference could be related to differences in the biology of the strains (efficiency and speed of replication for example).
Since these strains are agronomically relevant field isolates, they have not been extensively studied in laboratories and therefore little is known about their biology.

Two lines with the polyribozyme from plasmid pBPL4771 have a satisfactory phenotype when challenged with both strains and have been selected for a field trial which is taking place in summer 98 , after a satisfactory molecular profile was obtained for them.

Table 10. Inhibition of the Various Reporter Genes by Ribozyme Constructs

\begin{tabular}{lccl}
\hline Target & Ribozyme & Inhibition in \% & Comments \\
\hline 0184 & 0189 & 0 & $\begin{array}{l}\text { Site } 694 \text { - of WMV2 is very resistant to short and long arm } \\
\text { ribozyme. It also shows that the ribozyme plasmid by itself } \\
\text { has no inhibitory effect on the reporter 0plasmid expression. }\end{array}$ \\
0184 & 0195 & 0 & $\begin{array}{l}\text { Site } 994 \text { - of WMV2 is moderately susceptible to short arm } \\
\text { ribozyme. The lack of inhibition by the long arm ribozyme } \\
\text { could be explained by the lower molar quantity of the long } \\
\text { arm ribozyme plasmid. }\end{array}$
\end{tabular}

\begin{tabular}{|c|c|c|c|}
\hline $\begin{array}{l}0186 \\
0186\end{array}$ & $\begin{array}{l}0189 \\
0189\end{array}$ & $\begin{array}{l}75 \\
77\end{array}$ & $\begin{array}{l}\text { Site } 1747 \text { - of WMV2 is very susceptible to ribozyme. This } \\
\text { level of inhibition was the highest ever observed in this kind } \\
\text { of experiments. The experiment was done twice. }\end{array}$ \\
\hline 0186 & 0190 & 68 & $\begin{array}{l}\text { Site } 1747 \text { - of WMV2 is also susceptible to the ribozyme } \\
\text { directed against the identical sequence in ZYMV. In ribozyme } \\
0190 \text {, the total arm length (helix I + helix III) is } 16 \text { bases, } \\
\text { while in ribozyme } 0189 \text {, it is } 22 \text { bases. }\end{array}$ \\
\hline $\begin{array}{l}0199 \\
0199\end{array}$ & $\begin{array}{l}0189 \\
0190\end{array}$ & $\begin{array}{l}51 \\
42\end{array}$ & $\begin{array}{l}\text { The non cleavable allele (GUG) of site } 1747 \text { is less susceptible } \\
\text { to ribozyme inhibition than the cleavable (GUA) allele. } \\
\text { Nevertheless the level of inhibition (which we explain by } \\
\text { antisense effect) is surprising considering that the pairing } \\
\text { region is so small ( } 22 \text { or } 16 \text { bases). This site is probably very } \\
\text { accessible to inhibiting RNA molecules. }\end{array}$ \\
\hline 0186 & 0195 & 58 & $\begin{array}{l}\text { The long arm ribozyme is not more efficient that the short } \\
\text { arm ribozyme on site } 1747 \text { - of WMV } 2 \text {. The difference in the } \\
\text { level of inhibition is explained by the slightly smaller molar } \\
\text { quantity of long arm ribozyme plasmid used. }\end{array}$ \\
\hline $\begin{array}{l}0187 \\
0187\end{array}$ & $\begin{array}{l}0189 \\
0195\end{array}$ & $\begin{array}{l}20 \\
10\end{array}$ & Site 2066 - of WMV2 is moderately susceptible to ribozym \\
\hline $\begin{array}{l}0188 \\
0188\end{array}$ & $\begin{array}{l}0189 \\
0197\end{array}$ & $\begin{array}{l}70 \\
40\end{array}$ & $\begin{array}{l}\text { The region of the plus strand of WMV } 2 \text { used in the assay is } \\
\text { susceptible to the ribozyme but the assay did not allow us to } \\
\text { distinguish between the various sites. Long arm and short arm } \\
\text { seem to inhibit the target similarly once the molar quantity of } \\
\text { the ribozyme plasmid is taken into account. }\end{array}$ \\
\hline
\end{tabular}




\section{Transient Assay of Polyribozymes in Tobacco Cells}

The transient assay designed by Sawyer and Birch (12) to study antisense and ribozyme activity in plant cells was used to analyse several polyribozyme genes described above. A reporter gene was built by fusing in-frame WMV2 sequences containing one (for the minus strand, - in the table below), or four (for the plus strand, + in the table below) ribozyme target site(s) to the coding sequence of luciferase. Ribozyme genes identical to the genes described above but with the same promoter as the reporter gene were co-delivered in equal mass amount with the reporter gene in tobacco suspension culture cells by particle bombardment. The amount delivered corresponds to a molar ratio of ribozyme plasmid to target plasmid of between 1 and 1.5. Twenty four hours after co-delivery, the amount of luciferase was determined and the inhibition caused by the ribozyme plasmid was calculated. Each assay was done in triplicate; the standard error was always about $2-5 \%$ of inhibition; plasmid quantity was measured by spectrophotometry and plasmid quality was checked by ethidium bromide staining on agarose gels. The plasmids used are described in Table 9, and the results are in Table 10.

The results of the transient assay are consistent with the results obtained in planta to a large extent. However no significant difference in activity between long and short arm ribozymes could be detected in the transient assay whereas it seems that long arm ribozymes were more efficient in planta. One has to be prudent with regards to the in planta results because of the small number of independent transgenic plants tested. Nevertheless we can formulate several hypothesis to explain this observation: long arm ribozyme molecules could be more stable in the cytoplasm than their short arm equivalent, or they could inhibit the virus through several simultaneous mechanisms not relevant in the transient assay.

The transient assay has identified one conserved site on the viral minus strand (1747 in WMV2 and 1743 on ZYMV) that appears very sensitive to inhibition. The recent preliminary observation that a polyribozyme against WMV2 had some effect in planta on one strain of ZYMV would (if confirmed) establish that one single ribozyme activity against this site plays a significant role in the protection observed using polyribozyme.

\section{Conclusion}

The system we are working on (resistance of a transgenic crop plant to viruses) is not ideal to study basic questions about ribozyme functionality in vivo. The use of polyribozymes further complicates that matter. However the high rate of success, that is the relative easiness with which transgenic resistant plants could be obtained is encouraging for this application of the ribozyme technology in agricultural biotechnology. The Gene Shears shareholders and licensees will actively pursue this and other uses of the ribozyme technology in crops.

\section{References}

1. Tricoli, D.M., Carney, K.J., Russell, P.F., Russell McMaster, J., Groff, D.W., Hadden, K.C., Himmel, P.T.,
Hubbard, J.P., Boeshore, M.L., and Quemada, H.D. 1995. Field evaluation of transgenic squash containing single or multiple virus coat protein gene constructs for resistance to Cucumber Mosaic Virus, Watermelon Mosaic Virus 2, and Zucchini Yellow Mosaic Virus. Biotechnol. 13: 1458-1465.

2. Zankowski, P. 1997. Personal communication.

3. Lenée, P., Perez, P., Gruber, V., Baudot, G., and Ollivo, C. 1993. French Patent $n^{\circ}$ FR9302269.

4. Haseloff, J., and Gerlach, W. 1988. Simple RNA enzyme with new and highly specific endoribonuclease activities. Nature. 334: 585-591.

5. Perriman, R., Delves, A., and Gerlach, W.L. 1992. Extended target site specificity for a hammerhead ribozyme. Gene. 113: 157-163.

6. Perez, P., Tiraby, G., Kallerhof, J., and Perret, J. 1989. Phleomycin resistance as a dominant selectable marker for plant cell transformation. Plant Molec. Biol. 13: 365-373.

7. Firek, S., Ozcan, S., Warner, S.A., and Draper, L. 1993. A wound induced promoter driving nptll expression limited to dedifferentiated cells at wound sites is sufficient to allow selection of transgenic shoots. Plant Molec. Biol. 22: 129-142.

8. Betzner, A.S., Oakes, M.P., and Huttner, E. 1997. Transfer RNA-mediated suppression of amber stop codons in transgenic Arabidopsis thaliana. Plant J. 11: 587-595

9. Sullenger, B.A., and Cech, T.R. 1993. Tethering ribozymes to a retroviral packaging signal for destruction of viral RNA. Science. 262: 1566-1569.

10. Atkins, D., Young, M., Uzzell, S., Kelly, L., Fillatti, J., and Gerlach, W.L. 1995. The expression of antisense and ribozyme genes targeting citrus exocortis viroid in transgenic plants. J. Gen. Virol. 76: 1781-1796.

11. Yang, X.C., Yie, Y., Feng, Z., Liu, Y.L., Kang, L.Y., Wang, X.F., and Tien, P. 1997. Ribozyme-mediated high resistance against potato spindle tuber viroid in transgenic potatoes. Proc. Natl. Acad. Sci. USA. 94: 4861-4865.

12. Sawyer, B., and Birch, R. 1996. A generic transient assay for antisense and ribozyme inhibition in vivo. Proc. Australian Soc. Biochem. Molec. Biol. 28: POS320-02.

13. Allison, R.F., Greene, A.E., and Schneider W.L. 1997. Considering the risks of virus resistant transgenic crops. In: Commercialisation of Transgenic Crops: Risk, Benefit and Trade Considerations. G.D. McLean, P.M. Waterhouse, G. Evans, and M.J. Gibbs, eds. Cooperative Research Centre for Plant Science and Bureau of Resource Sciences, Canberra, Australia. p. $145-150$.

14. Beachy, R.N., Loesch-Fries, S., and Tumer, N.E. 1990. Coat-protein mediated resistance against virus infection. Ann. Rev. Phytopathol. 28: 451-474.

15. Elion, E.A. 1995. Constructing recombinant DNA molecules by the polymerase chain reaction. In: Current Protocols in Molecular Biology. F.M. Ausubel, R. Brent, R.E. Kingston, D.D. Moore, J.G. Seidman, J.A. Smith, and K. Struhl, eds. J. Wiley and Sons, New York. p. 3.17.1-3.17.10. 


\section{Further Reading}

Caister Academic Press is a leading academic publisher of advanced texts in microbiology, molecular biology and medical research. Full details of all our publications at caister.com

- MALDI-TOF Mass Spectrometry in Microbiology Edited by: M Kostrzewa, S Schubert (2016) www.caister.com/malditof

- Aspergillus and Penicillium in the Post-genomic Era Edited by: RP Vries, IB Gelber, MR Andersen (2016) www.caister.com/aspergillus2

- The Bacteriocins: Current Knowledge and Future Prospects Edited by: RL Dorit, SM Roy, MA Riley (2016)

www.caister.com/bacteriocins

- Omics in Plant Disease Resistance Edited by: V Bhadauria (2016) www.caister.com/opd

- Acidophiles: Life in Extremely Acidic Environments Edited by: R Quatrini, DB Johnson (2016) www.caister.com/acidophiles

- Climate Change and Microbial Ecology: Current Research and Future Trend

Edited by: J Marxsen (2016)

www.caister.com/climate

- Biofilms in Bioremediation: Current Research and Emerging Technologies

Edited by: G Lear (2016)

www.caister.com/biorem

- Microalgae: Current Research and Applications Edited by: MN Tsaloglou (2016) www.caister.com/microalgae

- Gas Plasma Sterilization in Microbiology: Theory, Applications, Pitfalls and New Perspectives Edited by: H Shintani, A Sakudo (2016) www.caister.com/gasplasma

- Virus Evolution: Current Research and Future Directions Edited by: SC Weaver, M Denison, M Roossinck, et al. (2016) www.caister.com/virusevol

- Arboviruses: Molecular Biology, Evolution and Control Edited by: N Vasilakis, DJ Gubler (2016) www.caister.com/arbo

- Shigella: Molecular and Cellular Biology Edited by: WD Picking, WL Picking (2016) www.caister.com/shigella

-Aquatic Biofilms: Ecology, Water Quality and Wastewater Treatment

Edited by: AM Romaní, H Guasch, MD Balaguer (2016)

www.caister.com/aquaticbiofilms

- Alphaviruses: Current Biology

Edited by: S Mahalingam, L Herrero, B Herring (2016)

www.caister.com/alpha

- Thermophilic Microorganisms

Edited by: F Li (2015)

www.caister.com/thermophile
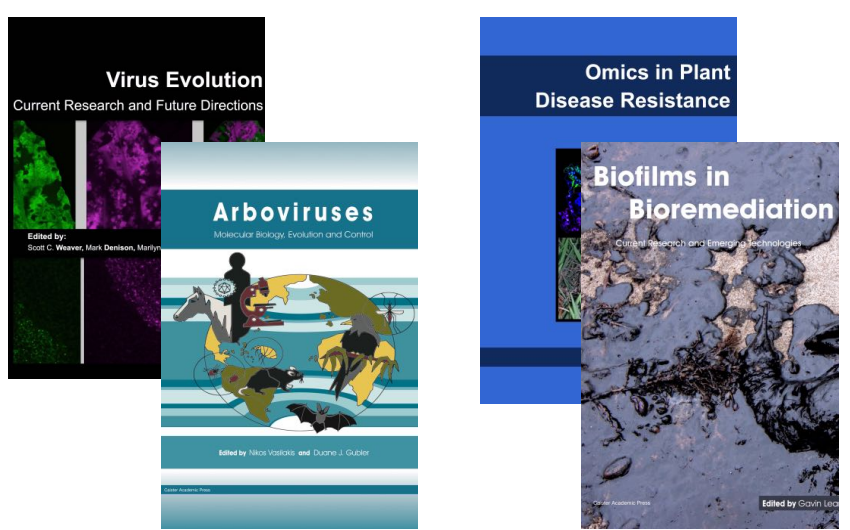
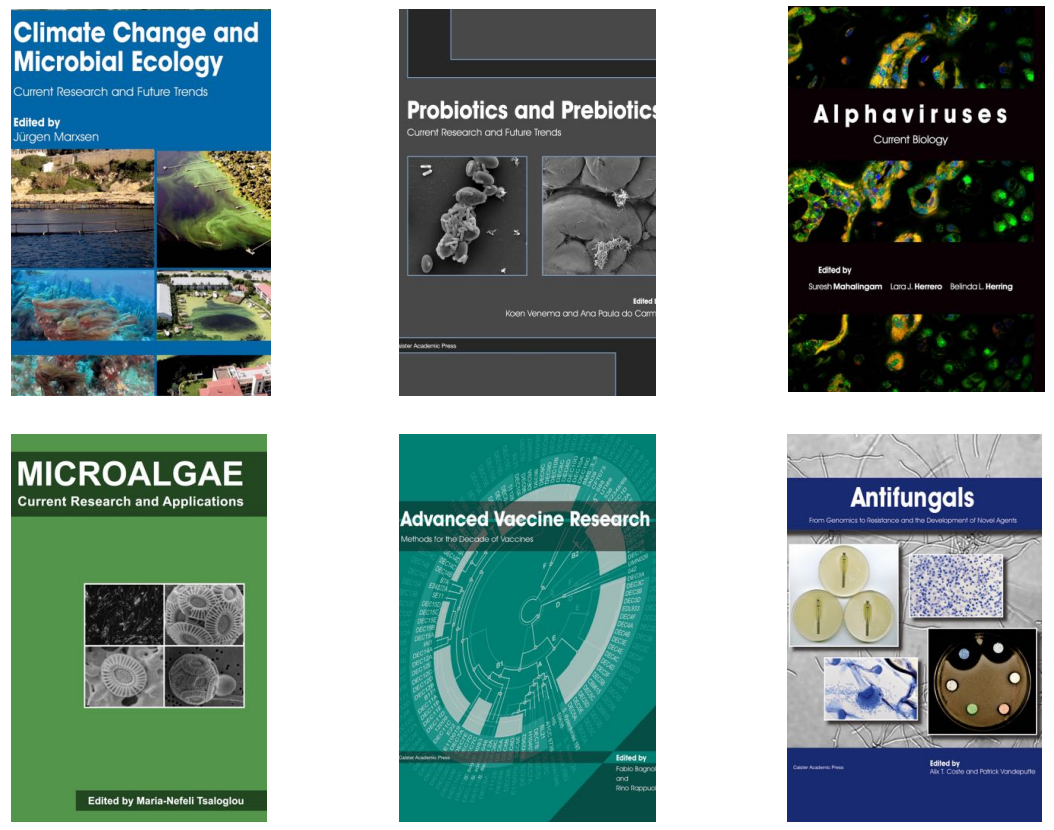

- Flow Cytometry in Microbiology: Technology and Applications Edited by: MG Wilkinson (2015) www.caister.com/flow

- Probiotics and Prebiotics: Current Research and Future Trends Edited by: K Venema, AP Carmo (2015) www.caister.com/probiotics

- Epigenetics: Current Research and Emerging Trends Edited by: BP Chadwick (2015) www.caister.com/epigenetics2015

- Corynebacterium glutamicum: From Systems Biology to Biotechnological Applications

Edited by: A Burkovski (2015)

www.caister.com/cory2

- Advanced Vaccine Research Methods for the Decade of Vaccines

Edited by: F Bagnoli, R Rappuoli (2015)

www.caister.com/vaccines

- Antifungals: From Genomics to Resistance and the Development of Novel Agents

Edited by: AT Coste, P Vandeputte (2015)

www.caister.com/antifungals

- Bacteria-Plant Interactions: Advanced Research and Future Trends Edited by: J Murillo, BA Vinatzer, RW Jackson, et al. (2015) www.caister.com/bacteria-plant

\section{- Aeromonas}

Edited by: J Graf (2015)

www.caister.com/aeromonas

- Antibiotics: Current Innovations and Future Trends

Edited by: S Sánchez, AL Demain (2015)

www.caister.com/antibiotics

- Leishmania: Current Biology and Contro Edited by: S Adak, R Datta (2015) www.caister.com/leish2

- Acanthamoeba: Biology and Pathogenesis (2nd edition) Author: NA Khan (2015)

www.caister.com/acanthamoeba2

- Microarrays: Current Technology, Innovations and Applications Edited by: Z He (2014)

www.caister.com/microarrays2

- Metagenomics of the Microbial Nitrogen Cycle: Theory, Methods and Applications

Edited by: D Marco (2014)

www.caister.com/n2 